Paper received: August $18^{\text {th }} 2015$ Paper accepted: September $22^{\text {nd }} 2015$

Sheila Padiglia, MA

HEP-BEJUNE, Switzerland

Original Paper

Francesco Arcidiacono, PhD

HEP-BEJUNE, Switzerland

DOI:10.5937/inovacije1503083P

\title{
A narrative format design to improve language acquisition through social interaction
}

\begin{abstract}
In this paper we present a research design devoted to create opportunities of learning and development through social interaction. The study is part of a EU project called SOFT (School and family together for the immigrant children integration) that aims to favor linguistic and social integration of children through language learning activities that connect families and schools.

Cultural and linguistic diversities are considered as elements promoting learning and cooperation among different social actors: children, teachers, parents, researchers and schools. In the present paper, we will discuss two aspects: 1) how the pedagogical design named "Narrative format " can establish a peculiar social interaction in the classroom and how, in a developmental perspective, it offers a real opportunity of cognitive and social skills improvement; 2) how social interactions between school and families help teachers, pupils and parents to develop an awareness of their roles and a strengthen their collaboration.

We have involved 15 teachers and 169 children (aged 3-7 years old) of three classes of primary schools and two kindergarten classes in Switzerland, proposing a design that provides pedagogical materials and activities devoted to teach/learn English and German language. The main questions of our study are the following: How teachers implement the pedagogical design in order to involve children in activities based on an unknown language? How does the narrative format help children learn to speak the new language and to enable the integration between teachers, children and parents? The results of our study show that the design we have implemented can create conditions that facilitate and imitate the natural (informal, discursive) acquisition of languages.
\end{abstract}

Key words: narrative format, multilingualism, social inclusion, school-family interactions

\section{Introduction}

This paper aims to illustrate how a research design devoted to create opportunities of learning

1 Sheila.Padiglia@hep-bejune.ch and development through social interaction has been implemented within an educational context. The study we will present is part of a EU project that has been conducted in order to favor the linguistic and social inclusion of children through language 
learning activities that connect families and schools. Our interest in these activities that are usually accomplished through social interactions relies on the idea that cultural and linguistic diversities are useful elements to promote learning and cooperation among different social actors in schools: children, teachers, parents, and researchers.

In the present paper, we will focus on two aspects of our research design: 1) how the pedagogical design named «narrative format» can establish a peculiar social interaction in the classroom and how, in a developmental perspective, it offers a real opportunity of cognitive and social skills improvement; and 2) how social interactions bridging school and families help teachers, pupils and parents to develop an awareness of their roles in processes of socialization and strengthen their collaboration towards social inclusion. Through the presentation and the discussion of the educational setting we have implemented, we intend to answer the following research questions: How teachers implement the pedagogical design in order to involve children in activities based on an unknown language? How does the narrative format help children learning to speak a new language and enables the integration between teachers, pupils and parents?

In the first part of the paper we will briefly present the framework within which our project has been conceived and developed. Afterwards, the main elements of our research will be described, with a specific focus on the different steps that the design implied within the educational settings of our study. Finally, some elements of reflection emerging from the results will be offered in the last section of the paper, in order to highlight to what extent the design we have implemented can create conditions that facilitate the natural acquisition of language.

\section{A theoretical framework for the narrative format design}

Our focus on the linguistic integration of children through social interactions, based on the language acquisition through activities that connect families and schools, is related to the political and societal context in which our project has been developed. In fact, in Switzerland the relevance of social inclusion issues remains current and very important, because the Swiss context is progressively confronted with an increasing heterogeneity in terms of cultures and languages spoken in schools. We consider language as a mean of social inclusion in this complex situation within primary contexts of education (such as schools and families), and as a possible way towards the establishment of effective and inclusive social practices. In order to define a synthetic framework, but broad enough to understand the nature of the project that is presented, we will refer to some key concepts that constitute useful frames to define the context of our research and its assumptions.

The first element we intend to present is connected to the integrative aim of different educational activities in schools that are more and more confronted to new societal forms shaped by movements of immigration. In our view, the social inclusion can be achieved through the creation of situations of social interactions throughout daily life. Different forms of interaction are at the core of the process by which people can regulate activities in formal and informal contexts: more specifically, throughout language and dialogue, the ability to interact can become a product of this discursive process of co-construction and integration. This approach is inspired by the work of Piaget (1926) and Vygotskij (1934), and is useful in the perspective of understanding the dimensions of thought's processes, and to study the conditions that allow interactions to promote apprenticeships. Social interactions are not considered as external elements or as composite variables that affect cognitive development and learning: rather, they are a set of indi- 
vidual and collective dimensions related to language, communication, people's intentions, goals, social representations and results of the dynamics in which adults and children interact.

A second element of our presentation concerns the idea that learning is always learning in context, based on the modalities through which cognition and acquisition of knowledge are formed within social interactions. The sociocultural perspective (Wertsch, 1985; Rogoff, 1990; Valsiner, 1995; Pontecorvo \& Arcidiacono, 2010, 2014) is very useful in this endeavour, because the primary contexts of interaction (e.g., families and schools) are considered to be the proper frameworks to offer opportunities to children (and adults) to enhance learning, critical attitudes and socialization processes (Resnick, Pontecorvo \& Säljö, 1997; Arcidiacono, 2013). Language thus becomes a procedure of thought used in different activities and in multiple contexts: more particularly, language socialization (Ochs \& Schieffelin, 1984; Schieffelin \& Ochs, 1986) is assumed as a process that never ends (Ochs, 1990), because each interaction is, in a potential way, an experience of socialization, of becoming member of a community, and an opportunity of creation and sharing of meanings (Bruner, 1983).

The third element refers to the notion of intersubjectivity that has been adopted in several approaches and that can be referred to a variety of objects of study. In our case, intersubjectivity concerns a co-construction of shared meanings (Bruner, 1998) done by the participants during different social activities. The possibility that intersubjectivity between people occurs is related to the possibility to create a shared space, to assume the overcoming from the own private world to the assumptions of the other's universe. This way of creating relationships between people could promote social inclusion and the establishment of socialization processes in educational contexts. In particular, the activity of teaching and learning in classroom can be considered in terms of «events because of their inter- actional nature and their sequential organization, in which talking shifts from party to party as the event unfolds and as a hierarchic structure marked by recurrent behavioural configurations» (Arcidiacono \& Gastaldi, 2011, p. 2).

The above-mentioned approach and the keyelements included in the first part of this paper constitute the framework within which the project we have implemented is based. In our idea, it is relevant to highlight that our interest is not exclusively based on the level of linguistic integration of native and immigrant children through the learning of a new language (including the language of the host country). On the contrary, we assume that learning languages, including those spoken by migrant children at home, and sharing experiences at school and family are both relevant elements. They have to be taken into account in the implementation of an educational research design devoted to the promotion of integrative practices in different settings. For this reason, we will introduce and present the project we have conducted to favor the linguistic and social inclusion of children through language learning activities that specifically connect families and schools.

\section{SOFT: A project connecting schools and families}

The project "School and family together for the integration of immigrant children", called SOFT", has been conceived by an interdisciplinary research team, starting from a common interest in language teaching/learning in multicultural contexts. Among the questions raised by the project and on which we will return later on (with details on its implementation in Western Switzerland), a key point that we will discuss in this paper is the central question of

2 Project $\mathrm{n}^{\circ}$ 531208-LLP-2012-IT-KA2-KA2MP - grant agreement: 4479-2012, Executive Agency of the European Commission for Education, Audiovisual and Culture, «European Union Lifelong Learning» program. We are grateful to the European Commission for the financial support and to the participant schools and families for their engagement. The present paper and its content remain under the responsibility of the authors. 
the specific connection between schools and families. This aspect is particularly relevant in terms of social interaction practices that can sustain the processes of learning and teaching, because it involves all the actors participating in the primary contexts of education, such as families and schools.

The research project includes different entities coming from five different European countries (Italy, Germany, UK, Spain and Switzerland) ${ }^{3}$ working together in order to develop pedagogical activities related to a double perspective: firstly, the fact that a constructive relationship between school and family potentially produces benefits for both adults and children; secondly, that previous research experiences (e.g., the projects Socrates Lingua "The Adventures of Hocus and Lotus", 1997-2000; “The Di-

3 The first partner is the University of Rome "Sapienza" (Italy), leading the network of participants and conducting the research at pre-school and primary level. The activities are performed in collaboration with the research team of the University of Rome 3 (Italy), that is in charge to investigate the influence of prejudices and stereotypes in the integration process of children from immigrant backgrounds and to analyze the relations between schools and families. A third partner is the Dinocroc International Training Institute in Rome (Italy) that deals with the production and publication of the necessary pedagogical equipment used in the project, as well as the organization of training courses about the narrative format for teachers of different degrees. The Kommunalen Integrationszentren in Essen (Germany) is the partner in charge to create designs and opportunities of collaboration for native and migrant children and their families. They provide training and mentoring activities as part of a working network including children, adolescents, families, teachers, speech therapists and political authorities. In Spain, the monitoring of the project is guaranteed by the Escuela de Negocios y Administracion de Empresas in Barcelona, a training institution specialized in language issues, administrative management and new technologies. From a scientific point of view, the project relies on the contributions of the research team based at the University of Edinburgh (Scotland), with a specific focus on the development of bilingualism and, in the Swiss context, on the activities guaranteed by the University of Teacher Education BEJUNE in Biel/Bienne. Our research team acts as Swiss partner within the project, ensuring the development and the promotion of research around the topics of cultural and linguistic heterogeneity, social representations and practices of teaching/learning processes in kindergarten and primary schools. nocrocs grow up", 2001-2004; "Let's become a bilingual family", 2010-2012) have empirically shown the benefits of learning a new language through specific educational programs. For this reason, the project we are presenting here uses a pedagogical program inspired by the narrative model format (for further details, cf. the project website: www.softintegration. eu) in order to promote the social inclusion of immigrant and native children in different countries. Training proposed to the participant teachers and a series of activities connecting families and schools are relevant part of the pedagogical design of the SOFT project, and will be presented in the following part of this paper.

\section{Multilingualism: The narrative format as a pedagogical tool based on social interactions}

Switzerland is a multilingual country. Four national languages co-exist and determine a particular context characterized by heterogeneity, diversity and multiple linguistic and cultural resources. Owning two or more languages is then usual and important not only because it gives to children the opportunity to understand cultures or sub-cultures within the same country, but also because bilingualism and multilingualism bring cognitive advantages, early acquisition of words, structures and sounds of languages. In fact, children that are immersed in bilingual or multilingual contexts often learn to read before others and they usually find easier to learn additional languages (Bialystok, 1986). Bilingual children are also able to be more attentive, less distracted by irrelevant information, and they can more easily move from one task to another. Many of these benefits were found in adults who have grown up as bilingual. Indeed, the effects of bilingualism and multilingualism have a significant impact on the mental capacities of individuals from childhood until adulthood (Sorace, 2007), for example in terms of mental flexibility (Ghimenton, 2014). The aim of this paper is not to discuss the notions of bilingualism and multilingualism (the reader can refer to a 
large literature on the topic: for a synthetic review, cf. Arcidiacono, 2014; for other sources, cf. Weinreich, 1968; Mackey, 2000; Grosjean, 2013). The objective is to present a pedagogical tool (namely, the narrative format) that has been conceived and used as a model of teaching/learning languages with children. Some elements of the implementation of this model in the Swiss context will also follow in the next sections of the paper.

The narrative format is a psycholinguistic model of language education for children in kindergarten, primary school and nursery. The label has been created by Taeschner (2005), clearly inspired by the fundamental work of Bruner on the notion of format (Bruner, 1998): “The acquisition of language begins before the child issued its first lexical-grammatical speech. It begins when the mother and the child create a predictable interaction format that can serve as a microcosm for communication and the creation of a shared reality. Transactions that occur in such formats are the 'input' from which the child can master the grammar, how to refer and mean, and how to achieve his intentions by communicating" (pp. 128-129, our translation). These notions of "predictable interaction" and creation of a shared reality constitute the core of our interest.

The model of teaching/learning languages through the narrative format was developed through the careful study of the natural process of acquiring two languages at home. It includes a series of educational strategies, activities and materials that create the appropriate conditions for learning a new language (Taeschner, 2002, 2003; Taeschner et al., 2008; Pirchio et al., 2014). Indeed, teaching a language is not easy, especially if one does not apply an effective method. Many families whose parents speak different languages are in trouble, despite the fact that they have a perfect knowledge of the language to be taught. Facilitating the learning of two (or more) languages is a constant of the narrative format, such as to establish effective and positive communication in relation to each other (peer, adult, caregiver). In this sense, the format is not only a tool to teach/learn languages, but it is a way to facilitate good emotional relationships and communicative acts among participants during social interactions within and outside the classroom.

The narrative format model has so far been successfully tested in more than 120 schools and is currently used by more than 4000 teachers across Europe. Four fundamental concepts are sustaining the narrative format approach:

- the principle of the narrative form of the thought that assumes that learning a foreign language is possible in a way that is analogous to the process of the first language acquisition. This implies the value of repetitive experiences, shared by the child with others (specifically, the adults), the use of storytelling, with the support of gestures and mimic allowing the meaning of words and phrases to be learnt through active work;

- the principle of good communication implying that an emotional bond among the conversational partners is essential to learn to speak. Establishing a relationship of affection and complicity is a key to motivate interlocutors and to improve their desire to communicate;

- the principle of using a language per situation (bilingualism) assumes that choosing and keeping a common language of conversation (e.g. English for French speaking people) is the condition for avoiding communication in the everyday local language and for sharing the chosen foreign language during joint activities;

- the principle of linguistic progression refers to the fact that the development of the vocabulary and language acquisition increases through a variety of experiences that are elaborated within different narrative formats. 


\section{A specific design to use the narrative format}

In order to use the narrative format (and its principles) in the classroom, we have developed a design consisting of a set of pedagogical material combined with different activities including children and adults.

In our research, we have involved 15 teachers and 169 children (aged three to seven years) of three classes of primary schools and two kindergarten classes in the Western part of Switzerland (French speaking cantons), proposing activities devoted to teach/learn English and German languages. Three main steps have been devoted to the implementation of the design: a first one dedicated to a specific teachers' training; a second step developing educational activities in the classroom; and a third one including joined activities with the families. We will present the pedagogical material conceived and these steps in the following part of the paper.

\section{The pedagogical material}

Our design is conceived around the adventures of Hocus and Lotus, two invented characters who teach languages to the participant children. Hocus and Lotus (see figure 1 below) have been created within the project in order to apply the narrative format in the context of children's activities at school and at home.

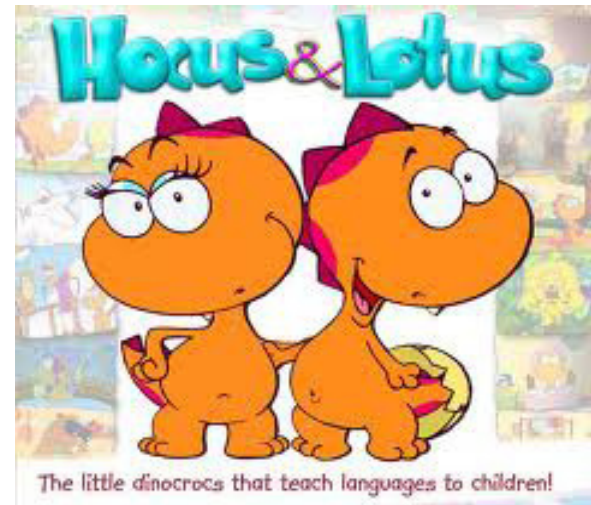

Fig. 1: Hocus and Lotus
The two protagonists of the stories are not people, but animals rather extravagant, designed with physical characteristics with which children can easily identify to. The pedagogical design is based on movies concerning the adventures of Hocus and Locus. These stories were written according to the demands of the teachers who previously experienced them in their classes. The adventures refer to the typical children's lives, everyday contexts and situations of real experiences, such as the identification of friends to play with, situations of sharing toys, discovering places, organizing new activities, and so on. The stories are organized in different episodes representing various adventures of Hocus and Lotus. Music and songs complete dialogues during the story-telling or movies. The texts of dialogues and monologues have been specifically developed to promote the process of language acquisition through repetition and to easily identify the relationship between images and spoken words.

According to the school grade levels foreseen in the project, a different set of educational materials has been made available to participants (teachers, children and families). The set of pedagogical tools (cf. figure 2) consist of a series of DVD including six episodes of "The Adventures of Hocus and Lotus" (the length of each episode is about 5 minutes) and six booklets with pictures and texts, according to the story of each episode. Books were offered to teachers, children and families and are written in five different languages (English, German, French, Italian and Spanish). Each participant received a CD with the songs of the different episodes, a small book with the texts of each song, a t-shirt and a bag with the characters of the story. Moreover, a guide presenting the goals of the project, the main principles of the narrative format, as well as examples of activities to be performed at school and at home have been offered to each participant. Guides were available in fifteen different languages (according to the nationalities of participant children) in order to be readable for immigrant parents. In addition, each teacher received a DVD and a book for his/her training 


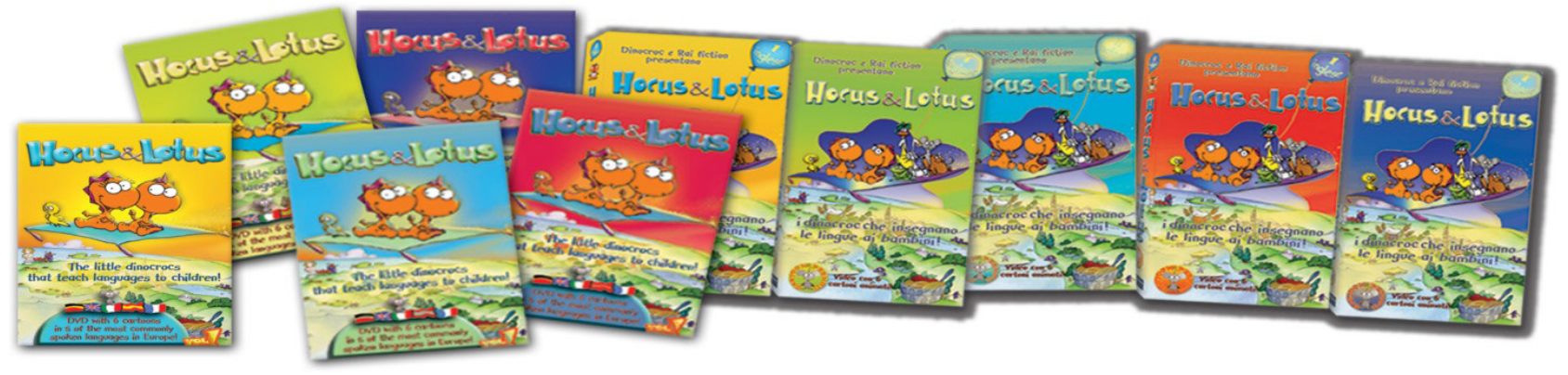

in narrative format. Teachers, in collaboration with the research team, settled the use of the pedagogical material in classrooms. Then, children were free to use the same material at home, involving parents and siblings during their time outside school. The different episodes, music and stories were conceived in order to promote the acquisition of the selected language through the verbal repetition and the visualization of the stories, and to stimulate the use of the material inside and outside the classroom.

\section{The Hocus and Lotus SING ALONGs}
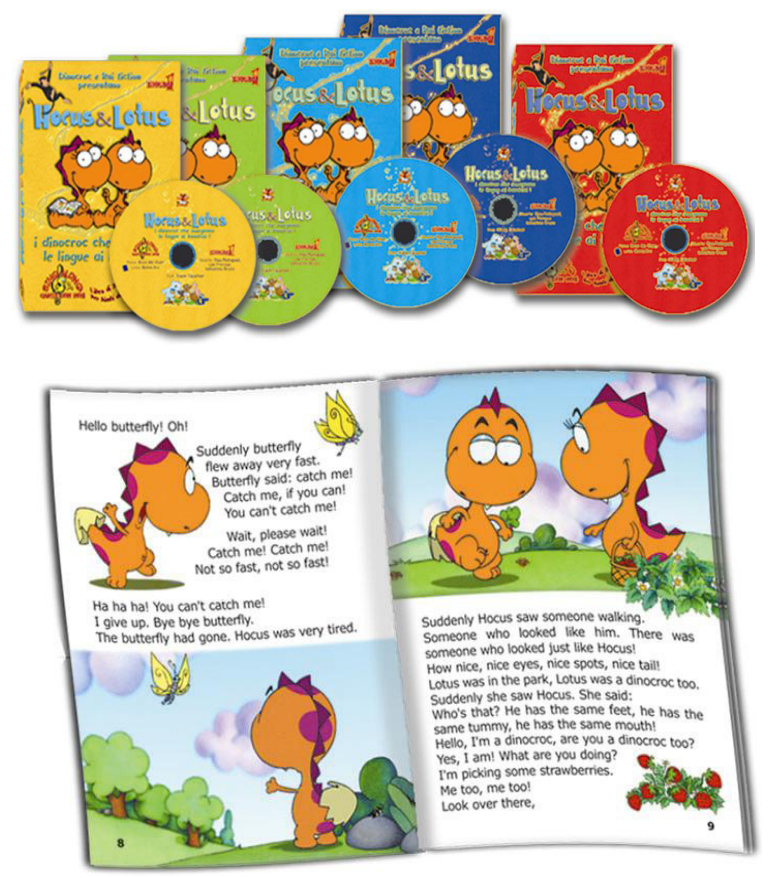

Fig. 2: The set of pedagogical material, DVD, CD and books.

\section{Step 1. Teachers' training}

Various sessions of training divided within thematic modules were organised with the participant teachers in order to introduce the main principles of the narrative format. Some of the topics of the training included items concerning interculturality, plurilingualism and school-families relations. Furthermore, specific DVDs devoted to the training, for different school degrees, were offered to the teachers in order to allow them to train themselves at home. The DVD explained and illustrated each narrative formats, through videos in which actors were playing each format (see Figure 3). Further explanations were given to teachers by the trainers (members of the research team) in order to highlight the importance of gestures and mimics which can differ from one language to another.

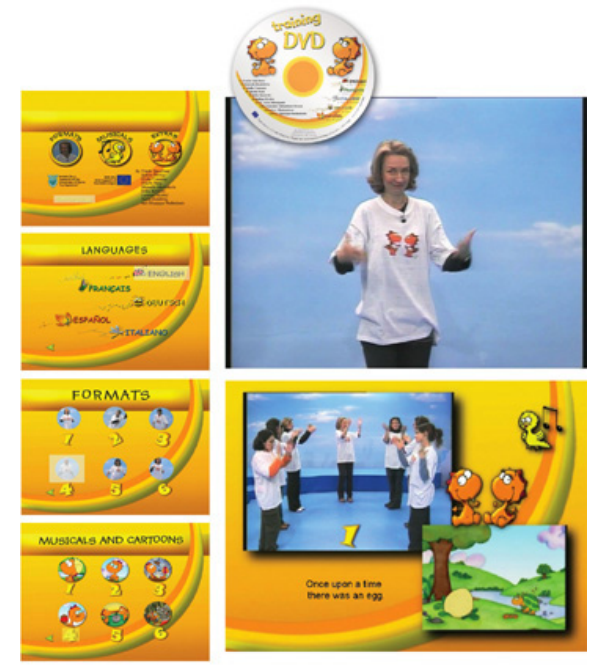

Fig. 3: DVD content with training activities for teachers 


\section{Step 2. The Narrative format with children in the classroom and at home}

After the training, teachers were ready to perform the narrative format with their pupils. As accounted through semi-directive interviews, teachers were very interested in trying this format in their classrooms, wondering if children would "play the game" and questioning themselves on whether the project would "enter" in home activities. Observations in the classrooms and post-activity interviews showed that pupils and teachers very well performed the "practical" part of the project. As the main idea of learning languages is based on the creation and reproduction of practices of good communication based on intersubjectivity and motivation to speak with others, the interactions of the narrative format take place through the establishment of spaces of communication where "routines" (intended as shared experiences) are performed. This type of activities allows each participant to play different roles of the various characters of the story, notably through the listening and acting out activities presented by the pedagogical material. The language of the stories is grounded in simple grammar and presents themes that are familiar to the children, mostly based on contexts of their everyday lives. During the narrative format, children learn the stories by repeating it with the teachers, by acting out the episodes and singing. This way to learn words, gestures and mimics through simple formats of 5 minutes each has been elaborated according to the following six steps: 1 . The opening format, a way to move from the real world of the mother tongue to the imaginary world of the adventures of Hocus and Lotus using a new language; 2 . The acting out of the story, a performance of the episode orally told by the teacher, and integrated by gestures and mimics; 3 . The musical, the moment in which children are singing the story, repeating the vocabulary and the expressions used in the acting out; 4 . The reading activity performed using the books that illustrate the stories; 5 . The cartoon, watched together in order to recall the story; 6 . The return to the real life, a final step that indicates to children that they are back from the imaginary world of the new language to the real world of the mother tongue.

According to our pedagogical design, children are requested to take the material at home and to freely repeat the formats alone or with other members of their family (e.g., singing or listening the music, watching the DVDs with parents or siblings, reading the book, etc.). The audio data collected during interviews with parents showed that they were really engaged in using the pedagogical material at home.

\section{Step 3. Teachers-parents shared activities}

A further level of our pedagogical design concerns the joint activities between families and schools that were organized by inviting parents and siblings at school. These meetings were organised twice in the school-year, and quite all invited parents were present. During these occasions, parents, children and teachers were working together around different subjects, such as intercultural education, mutual knowledge, and multilingualism as a resource for the society. According to the heterogeneous composition of the participant classroom and families, these activities have constituted invaluable opportunities to share different cultural and linguistic realities among adults and children. The engagement of all the actors involved in the project has made possible the organization of different activities at school (e.g., such as shows, games, picnics, activities of painting, etc.). These moments also were a space of sharing intercultural experiences based on opinions and testimonies on the project lines and on teaching/learning languages. Some parents were happy to use these moments as opportunities to share their own story of learner or agent of language transmission at home. 


\section{The implementation of the pedagogical design}

As said above, we have involved 15 teachers and 169 children (aged three to seven years) of three classes of primary schools and two kindergarten classes in the Western part of Switzerland (French speaking cantons). We have collected qualitative data, mainly through interviews (audio-recorded in step 1 and step 2) and observations (ethnographic notes and videos in step 2 and 3). Unlike other countries involved in the SOFT project, Switzerland has by its multilingual policy structure and migration flows a long reflection on language issues (foreign languages, L2), and not only on national languages (L1). Notably, the political decisions taken during the last two years for L1 and L2 in school in the French-speaking and German-speaking cantons make these language issues a public relevant topic. It is known that for any project, the time of the implementation becomes a time of negotiations and adaptations not always planned, even more when it comes to implement the same project in different realities (Padiglia, 2008). Concerning the SOFT project, the material and its use has been adapted to the peculiar context of the Swiss classrooms. Furthermore, even if Swiss teachers are mostly already struggling since several years with reflections on the use and learning of L2 and are often already integrated in scientific projects (e.g., the linguistic immersion projects), the SOFT project had the particularity to extend the reflection to other languages, not only those advised by the cantons. This aspect was particularly important to show that learning a foreign language enables and facilitates the learning process of the mother tongue. As already said, the reality of Swiss French-speaking classes asked for adjustments of our pedagogical design. In fact, the formats were originally meant for small group, but in Switzerland teachers were mostly alone with the whole classes of twenty or more students. Despite this basic difficulty, the classroom's observations showed that pupils could gladly participate to the narrative format not only by repeating the dia- logues and monologues of the stories, but also anticipating them.

At the beginning of the project, teachers shared their concerns about the implementation of the design in their classrooms (step 1), wondering if children and parents would really get involved. For example, a teacher of primary school, during an initial interview with the researchers, declared the following: "I will be happy if all the children get in the active part with the language which is the most difficult thing in a classroom of more than twenty pupils. Another aspect is about the fact that it should go into the families, that it should take a larger dimension."

In the implementation of the pedagogical design, an interesting aspect to be highlighted is the fact that teachers not only wanted to apply the formats, but they really get involved in the implementation process, trying to find new modalities and create better conditions for social inclusion of a large set of children. In that sense, teachers of primary school developed a new way of performing the format: the leading of the story was not only done by the teacher, but "advanced" pupils were also invited to teach - by reading and performing the narrative format - young children of other classrooms. As effect, the young children immediately were involved in participating to the format activity, although they were not yet familiar with the Hocus and Lotus stories. During different recorded sessions in the classroom, pupils were free to give their opinion on the activities they led, showing a good comprehension of the modalities in which the stories were set: for example, a child of primary school expresses as follows his way to intend what means learning a foreign language: "eh it's normal they (the characters of the stories) repeat because it's like that learning is working."

A relevant aspect in the implementation of the pedagogical design within the Swiss context concerns the benefits of parental involvement. As children received the material at home, it was possible to share it with their family. This has been an 
important way to appropriate spaces that bridged schools and families, because parents and children could then be "immersed" in the pedagogical scenario usually created in the classroom, re-activating it outside the school. An example are the new modalities of repeating the format in informal environments such as during car trips or at dinnertime. A mother of a child of primary school declared the following: "We (she and her daughter) were in the car and I have thought, I could have recorded this! [...] In the evening at table when my daughter has begun to repeat her sentences (about Hocus and Lotus stories) I have recorded it... We can also hear the cat and some other noises (laugh)." Through these practices, social interactions within and outside the school become factors to promote integrative practices and the development of new linguistic skills. In fact, the development of children's welfare and learning do not depend exclusively on individual factors and personal characteristics, but also on the quality of the contexts in which they live and interact. In turn, the children's settings of life (school, family, peer group) are not independent from each other, rather they in- fluence each other. The quality of these influences, the relationships between the various environments have an impact on the quality of children's learning and development.

The parental involvement in children's school experiences is a part of this educational process based on the partnership between the school and the family. These aspects are in line with evidences on children's well-being and growth that have been produced by research in the field of psychology. The relations that take place at school between parents and teachers are then recognized as most responsible elements for the education of children (Padiglia \& Arcidiacono, 2015).

Teaching a new language can be a bond of discussion between parents and teachers were everyone can share his/her own feelings and concerns. A mother of a child of primary school declared: "the teacher was surprised... in a positive way... about the evolution of some children. At the beginning of the school year she (the teacher) said: "oh dear it will be difficult for some children"... but some children

\begin{tabular}{|l|l|l|l|}
\hline $\begin{array}{c}\text { Name of the } \\
\text { activity }\end{array}$ & $\begin{array}{c}\text { People } \\
\text { involved }\end{array}$ & Material needed & \multicolumn{1}{|c|}{ Goal of the activity } \\
\hline $\begin{array}{l}\text { Guessing which } \\
\text { character of H\&L } \\
\text { we are (a frog?) }\end{array}$ & $\begin{array}{l}\text { - Teachers } \\
\text { - Children } \\
\text { - Parents }\end{array}$ & $\begin{array}{l}\text { - A bag } \\
\text { - A mirror } \\
\text { - H\&L characters (a } \\
\text { frog, a duck...) }\end{array}$ & $\begin{array}{l}\text { To involve parents in a dynamic } \\
\text { play with children and teachers } \\
\text { trying to find which character of } \\
\text { H\&L they are }\end{array}$ \\
\hline Operational description of the activity: The activity is performed in two times: \\
1) After having performed the 1 1t Format in which every character of the story has been \\
presented, the teacher gives to every child a toy representing a Hocus' friend: the \\
frog, the duck, etc... To the children having a duck she can ask: "are you a frog?" \\
And the child answers, "No, I'm not a frog"... \\
2) In a second time, the teacher hides one of the character (so he/she tells) in a bag \\
and ask the children to go and ask the parents to look in the bag and answer the \\
question "are you a frog?" or "are you a duck?"...the parent checks what is in the bag \\
and answers "No, I'm not a frog”... \\
3) At the end the teacher shows what was in the bag and the children discover a mirror \\
(of the format 1 story).
\end{tabular}


surprised her in a good way at the end of the shool year, they were not in diffficulty with German at all."

A fundamental opportunity of social inclusion was the possibility to organize meetings with parents, children and teachers. During these occasions, parents were involved in co-organizing, with teachers and children, different activities in classroom. In the table below there is an example of activity created by teachers, children and parents during a meeting. The activity concerns the capacity to ask and answer (in a selected language) questions about characters (frog, duck, etc.) that are in different bags.

Several studies have shown how the involvement of parents in school living has beneficial effects on children's success (Epstein et al. 1997). The key components of the partnership between school and family are based on the capacity to share and negotiate rules, to balance educational styles and attitudes, and to participate in the school-family experiences in various forms (such as sharing choices and decisions, through dialogues, active participation and capacity to recognize and to value other's contribution).

Among the objectives of the SOFT project, shared activities between teachers, parents and children are the key elements to build a common space of socialization and integration. As lesson learned by this implementation, we will strive for transmission in time and we already have available teachers to integrate the education model proposed by the SOFT project as part of their school activities thereafter.

\section{Discussion and conclusion}

As presented in the theoretical framework, the SOFT project relied on three core elements: integration through social interaction; learning in context; and intersubjectivity. Language learning, as it has been conceived in this project, shows how the narrative formats only live through social interac- tions, creating close social links in the classroom (through peer interactions or adult-child interactions), at home (with parents and/or siblings) and in home-school activities enabling shared spaces to foster social inclusion. As the pedagogical material we have implemented sustained these different types of social interaction, our design enabled to develop good communication practices and strengthen social relationships among participants. For example, children participating to the project have developed a stronger sense of alteration and intercultural differences, becoming, on the one hand, proud of their own origin and mother tongue (e.g., through direct questions to other pupils, such as "Are you Italian? Me too!"), and, on the other hand, developing a stronger interest in classmates own language (e.g., "How do we say friend in Turkish?"). Furthermore, the opportunities to strengthen the connection between families and schools have provided beneficial spaces for dialogue, also enabling the unity and potential improvement of the self-esteem of families, of their own identity and uniqueness, here considered as a positive resource by parents and by the school actors. In fact, some families coming from a minority ground often advise their own children not to speak the mother tongue, thinking that it could (negatively) interfere with the acquisition of the language of the host country. This shared space with families offered a concrete possibility to sustain their own language transmission, to share it with other parents, children and teachers, and to reflect on their own way of thinking about it. For example, a mother declared, during a meeting between teachers and parents, the following: "I have learned new languages only by the written and visual way, but they (children) learn by listening... and all that they can hear, it's incredible! (...) We (the parents) have the reflex to think that for learning a new language we have to do written activities, but they (children) understand everything and they don't even know how to read! Incredible! So that's cool!"

Last but not least, teachers have developed a more effective sense of comprehension of different 
issues concerning integration. Notably, the creation of meeting opportunities relying on language issues has open a new way of thinking the relationships with the parents, including them closely in the teaching/learning scenarios. The project also showed how learning is effectively only learning in context. In the design we used, every partner was taking advantages of different learning contexts, schools, families or in boundary-crossing these contexts and situations, creating "shared-spaces" as in school-families meetings or teacher-training activities. Every partner was developing learning skills that rely on these contexts and opportunities of mutual enrichment. The SOFT project finally showed how language learning relies on the capacity to create a common space where the co-construction of a shared meaning can arise, an intersubjective space which relies notably on the principle of good communication, postulating that the creation of an emotional bond among the conversational partners is essential to learn to speak a new language.

Besides what has been presented above, we would like to highlight few additional elements of pedagogical reflection. As seen, the SOFT project was aimed at providing benefits to all the various actors involved. In this sense, children using the peda- gogical material in classroom and at home were developing skills usually related to the bilingual and multilingual cognitive advantages. On the parents' side, an additional positive effect was that they were easily involved in the project and well-motivated to participate to school activities. They also were feeling invited to actively participate to their child's language acquisition, through sharing relational and learning experiences in different contexts and occasions. Finally, on the teachers' side, a strong positive issue relied on the fact that they have learned to create and develop different pedagogical scenarios involving school actors and families, promoting exchanges through collaborative, educational and linguistic skills. The teacher training sessions were an opportunity to sustain long life learning by sharing experiences with other colleagues of the school, where more experienced ones were reassuring or advising more inexperienced ones (including some teachers having some apprehension to change the own teaching style). We are aware that they will continue to transfer these good practices to new colleagues and that they will develop and adapt the pedagogical material with their future native and immigrant pupils.

\section{References}

- Arcidiacono, F. (2013). Conversation in educational contexts: School at home and home at school. In G. Marsico, K. Komatsu \& A. Iannaccone (Eds.), Crossing Boundaries. Intercontestual Dynamics between Family and School (pp. 83-107). Charlotte, NC: Information Age Publishing.

- Arcidiacono, F. (2014). Plurilinguisme et enseignement des langues: une vision d'ensemble. In F. Arcidiacono (Ed.), Hétérogénéité linguistique et culturelle dans le contexte scolaire (pp. 11-25). Biel/Bienne: HEP-BEJUNE.

- Arcidiacono, F., \& Gastaldi, F. G. M. (2011). "What do you say?” The analysis of classroom talk from a sociocultural perspective. Психолоїческая Наука и Образование / Psychological Science and Education, 2, 1-15.

- Bialystok, E. (1986). Levels of bilingualism and levels of linguistic awareness. Child Development, 57, 498510.

- Bruner, J. (1983). Child's talk: Learning to use language. New York, NY: Norton.

- Bruner, J. (1998). Le développement de l’enfant: savoir-faire, savoir dire. Paris: Presses Universitaires de France.

- Epstein, J. L., Coates, L., Salinas, K. C., Sanders, M. G., \& Simon, B. S. (1997). School, family and community partnerships: Your handbook for action. Thousand Oaks, CA: Corwin Press. 
- Ghimenton, A. (2014). Les vertus cachées du bilinguisme. Psychoscope, 6, 12-15.

- Grosjean, F. (2013). Bilingualism: A short introduction. In F. Grosjean \& L. Pi (Eds.), The Psycholinguistics of Bilingualism (pp. 5-25). Chichester: Wiley-Blackwell.

- Mackey, W. (2000). The description of bilingualism. In L. Wei (Ed.), The Bilingualism Reader (pp. 26-54). London: Routledge.

- Ochs, E. (1990). Misunderstanding children. In N. Coupland, H. Giles \& J. Wieman (Eds.), Handbook of Miscommunication (pp. 44-60). Clevedon: Multilingual Matters.

- Ochs, E., \& Schieffelin, B. B. (1984). Language acquisition and socialization: Three developmental stories. In R. Shweder \& R. LeVine (Eds.), Culture theory: Mind, self, and emotion (pp. 276-320). Cambridge: Cambridge University Press.

- Padiglia, S. (2008). An integrative view of the observation of implementation in the different sites: From dream to reality. In B. B. Schwarz (Ed.), ESCALATE's White Book on argumentation and enquiry-based science learning. Jerusalem: Hebrew University of Jerusalem.

- Padiglia, S., \& Arcidiacono, F. (2015). Towards integrative approaches through multilingual activities: Teachers, pupils and families experiencing a collaborative project. In M. Carmo (Ed.), International Conference on Education and New Developments. Proceedings (pp. 251-255). Lisbon: WIARS.

- Piaget, J. (1926). The language and thought of the child. London: Routledge.

- Pirchio, S., Taeschner, T., Passiatore, Y., \& Tomasini, G. (2014). Gagner le défi de léducation biblingue: l'application du modèle du Format Narratif à lécole et en famille. In F. Arcidiacono (Ed.), Hétérogénéité linguistique et culturelle dans le context scolaire (pp. 47- 59). Biel/Bienne: Editions HEP-BEJUNE.

- Pontecorvo, C., \& Arcidiacono, F. (2010). Development of reasoning through arguing in young children. Кульйурно-Истиорическая Психолоїия / Cultural-Historical Psychology, 4, 19-29.

- Pontecorvo, C., \& Arcidiacono, F. (2014). Social interactions in families and schools as contexts for the development of spaces of thinking. In T. Zittoun \& A. Iannaccone (Eds.), Activity of thinking in social spaces (pp. 83-97). New York, NY: Nova Science Publishers.

- Resnick, L. B., Pontecorvo, C., \& Säljö, R. (Eds.) (1997). Discourse, Tools and Reasoning: Situated Cognition and Technologically Supported Environments. Amsterdam: Springer.

- Rogoff, B. (1990). Apprenticeship in thinking: Cognitive development in social context. New York, NY: Oxford University Press.

- Schieffelin, B. B., \& Ochs, E. (1986). Language Socialization across Cultures. Cambridge: Cambridge University Press.

- Sorace, A. (2007). The more, the merrier: Facts and beliefs about the bilingual mind. In S. Della Sala (Ed.), Tall Tales about the Mind and the Brain: Separating Fact from Fiction (pp. 193-203). Oxford: Oxford University Press.

- Taeschner, T. (Ed.) (2002). L'insegnante magica. Rome: Borla.

- Taeschner, T. (2003). Il sole è femmina: uno studio sullacquisizione del linguaggio in bambini bilingui. Rome: DITI.

- Taeschner, T. (2005). The magic teacher. London: CILT. 
- Taeschner, T., Rinaldi, P., Tagliatatela, D., \& Pirchio, S. (2008). Le parole per raccontarmi. Una ricerca sull'apprendimento dell'italiano da parte di adolescenti figli di immigrati. Psicologia dell'educazione e della formazione, 10 (1), 21-35.

- Valsiner, J. (1995). Editorial: Discourse complexes and relations between social sciences and societies. Culture \& Psychology, 1, 411-422.

- Vygotskij, L. S. (1934). Myslenie i rec'. Psichologiceskie issledovanija. Moscow: Gosudarstvennoe Social'noEkonomiceskoe Izdatel'stvo. (English transl. Thought and Language. Cambridge: The MIT Press, 1962).

- Weinreich, U. (1968). Languages in Contact. The Hague: Mouton.

- Wertsch, J. V. (1985). Culture, Communication and Cognition: Vygotskian Perspectives. Cambridge: Cambridge University Press. 


\section{мср. Шила Падиља}

Универзитет за образовање наставника кантона Берн, Јура и Нојшател, Швајцарска

\section{др Франческо Арчидијаконо}

Универзитет за образовање наставника кантона Берн, Јура и Нојшател, Швајцарска

\section{Форма нарације осмишљена ради бољег усвајања језика кроз социјалну интеракцију}

У овом раду представљамо истраживање које је посвећено осмишљавању могућности за учење и развој кроз социјалну интеракцију. Ова студија представља део EU пројекта под називом СОФТ (School and family together for the immigrant children integration), а има за циљ бављење лингвистичком и социјалном инклузијом деце кроз активности у вези са учењем страног језика, којима се повезују породице и школе.

Културне и лингвистичке различитости се сматрају елементима који промовишу учење и сарадњу међу различитим учесницима у социјалној комуникацији: децом, наставницима, родитељима, истраживачима и школама. Заправо, ми обраћамо пажњу на образовне активности које се остварују кроз социјалну интеракцију и у којима културне и лингвистичке разноликости представљају корисне елементе који промовишу учење и сарадњу међу различитим учесницима у социјалној комуникацији.

У овом раду ћемо анализирати два аспекта нашег истраживања: 1) како педагошко истраживање под називом „форма нарације“ може да створи необичну социјалну интеракцију у учионици и како у развојној перспективи нуди праву могућност за побољшање когнитивних и социјалних вештина; 2) како социјална интеракција између школе и породица помаже наставницима, ученицима и родитељима да развију свест о својим улогама и да појачају сарадњу са социјалном инклузијом? Кроз презентацију образовног окружења, а касније и дискусију о томе, наша намера је да дамо одговоре на следећа истраживачка питања: како наставници спроводе педагошко истраживање ради укључивања деце у активности на страном језику; како форма нарације помаже деци да науче да говоре нови језик и како омогућава интеграцију наставника, ученика и родитеља?

Наш фокус је на лингвистичкој интеграцији деце кроз социјалну интеракцију која се заснива на усвајању језика кроз активности које повезују породице и школе, а у вези су са политичким и друштвеним контекстом у којем је и развијен наш пројекат. Питања која се тичу релевантности социјалне инклузије су веома актуелна у Швајцарској, јер се Швајцарска непрекидно суочава са све већом хетерогеношћу култура и језика који се говоре у школама. Језик се сматра средством социјалне инклузије у овој сложеној ситуацији у оквиру основних контекста образовања (као што су школе и породице) и као могући начин који води заснивању ефектне и инклузивне социјалне праксе. Сматрамо да је релевантно нагласити да наш интерес није искључиво заснован на нивоу језичке интеграције деце чији је то матерњи језик и деце имиграната кроз учење новог језика (укључујући језик земље домаћина). Напротив, претпостављамо да и школа и кућа представљају релеванте елементе за учење и матерњег и страног језика за децу мигранте.

Пројекат СОФТ је започео интердисциплинарни истраживачки тим, а полазна тачка је била заједничко интересовање за учење и поучавање језика у мултикултуралном контексту. Пројекат је покренуо многа питања, а централна питања и главни предмет су они који се тичу односа између школе и породице. Овај аспект је нарочито релевантан у смислу социјалне интеракције која одржава процес 
учења и поучавања, јер укључује све извршиоце који учествују у контексту основног образовања, као што су породице и школе. Циљ овог рада није дискутовање о схватањима билингвизма и мултилингвизма, већ представљање педагошке форме нарације која је започета и која користи модел учења/поучавања језика са децом. Да бисмо користили форму нарације (и њене принципе) у учионици, развили смо пројекат који се састоји од сета педагошких материјала који се комбинују са различитим материјалима, а у то су укључени и деца и одарасли. У ову студију је било укључено петнаест наставника и сто шездесет деветоро деце (узраста од три до седам година), из два разреда основне школе и две групе из обданишта у Швајцарској, а активности су се тицале учења/поучавања енглеског и немачког језика. Три главна корака су била посвећена имплементацији пројеката: први је посвећен посебној обуци наставника; други корак развијању образовних активности у учионици, а трећи заједничким активностима породице и школе. Сакупили смо квалитативне податке, углавном преко интервјуа (аудио-снимци у фазама 1 и 2) и посматрање (етнографски записи и видео-снимци у корацима 2 и 3 ).

Резултати овог истраживања показују да пројекат који смо имплементирали може да створи услове који помажу и имитирају природну средину (неформалну, дискурзивну) за усвајање језика. Посматрања у учионици су показала да ученици учествују у форми нарације, не само понављајући различите дијалоге и монологе неких прича већ и активно учествујући. Добре стране имплементације педагошког пројекта у швајцарском контексту обухватају и укључивање родитеља. Животно окружење деце као што су школа, породица и вршњачка група нису независне једна од друге, већ имају утицаја једна на другу. Квалитет ових утицаја и односи између различитих окружења имају утицаја на квалитет учења деце и на развој. Родитељско укључивање у школски живот деце је део образовног процеса, који се заснива на партнерству између школе и породице.

Коначно, могућности које чине снажнијим везу између породица и школа су створиле простор за дијалог, омогућавајући јединство и потенцијално побољшање самопоуздања породица, њиховог идентитета и јединства, које се овде сматрају позитивним фактором и породица и учесника у школовању. Заправо, неке породице које потичу из мањинских популација често саветују децу да не говоре матерњим језиком, мислећи да то може имати негативни утицај на усвајање језика земље у којој живе. Ово се односи и на породице којима је понуђена могућност суздржавања од матерњег језика на којем би разговарали са другим родитељима, децом и наставницима.

Кључне речи: наративни формат, вишејезичност, социјална инклузуја, интеракција између школе и породице. 